\title{
PENGEMBANGAN DAN STRATEGI PERLINDUNGAN HUKUM ATAS EKSPRESI BUDAYA TRADISIONAL DI KABUPATEN LEBAK
}

${ }^{1}$ Sulasno, ${ }^{2}$ Wahyuddin, ${ }^{3}$ Fitria Agustin

${ }^{1.3}$ Fakultas Ilmu Sosial, Ilmu Politik, dan Ilmu Hukum, Universitas Serang Raya, Serang, Banten.

${ }^{2}$ Fakultas Teknologi Informasi, Universitas Serang Raya, Serang, Banten.

Correspondent email : sulasno1971@gmail.com

$\begin{array}{lll}\mid \text { Article History } & : & \\ \mid \text { Submission } & : & \text { 21 April 2021 } \\ \mid \text { Last Revissions } & : & \text { 20 Juni 2021 } \\ \text { |Accepted } & : & \text { 23 Juni 2021 } \\ \text { | Copyedits Approved } & : & \text { 26 Juni 2021 }\end{array}$

\begin{abstract}
Abstrack
This Research is aimed at knowing the development and strategy of law protection against Traditional Cultural Expressions in the Lebak district. In this Research, theoretically useful for society's undergrad students. Practices are useful to both art and cultural users, of the Education and Cultural Services, of the Tourism service and associated agencies. But currently researchers have not found any particular protection against Traditional Cultural Expressions in the Lebak district. The expressions of traditional culture is a trademark of a people worthy of protection. The provision was intended to avoid the actions of foreigners who might damage cultural values. Since the role of the government to provide protection was necessary, it was necessary to bring out specific law. The qualitative work involves an empirical normative study method of law research by digging into the regulatory regulations. In addition to that researchers do retrieve direct data from communities.
\end{abstract}

Keywords: Development; Strategy; Protection; Culture; Intellectual Property. 


\section{A. PENDAHULUAN}

Budaya tradisional merupakan suatu karya yang tidak hanya perlu dikembangkan namun juga dilestarikan dan dimanfaatkan. Indonesia dikenal sebagai bangsa yang kaya akan seni dan budaya tradisionalnya. 1.128 suku tersebar di seluruh wilayah Indonesia dengan lebih dari 300 dialek bahasa dan lebih dari 3000 tarian asli Indonesia juga terdapat berbagai kesenian lain seperti lagu-lagu tradisional, kesenian adat daerah dan lainnya. ${ }^{1}$ Seni dan budaya tradisional atau disebut juga Ekspresi Budaya Tradisional (EBT) adalah sebagai identitas jati diri bangsa Indonesia yang dapat dimanfaatkan secara ekonomi untuk kemajuan dan kesejahteraan masyarakat. Oleh karena itu perlu adanya aturan berbentuk peraturan perundang-undangan khusus yang mengatur mengenai ekspresi budaya tradisional. Ekspresi budaya tradisional merupakan wujud material dari keragaman etnik dan suku bangsa di Indonesia. Sejauh ini, Indonesia termasuk ke dalam lima besar negara-negara di dunia yang memiliki kekayaan etnik tradisional yang paling beragam $^{2}$.

Pemerintah telah melakukan upaya-upaya perlindungan hukum yang tepat bagi ekspresi budaya tradisional dengan membuat RUU Perlindungan dan Pemanfaatan Kekayaan Intelektual Pengetahuan Tradisional dan Ekspresi Budaya Tradisional walau hingga saat ini belum diundangkan sebagai Undang-Undang. Pengaturan tentang ekspresi budaya tradisional dalam sistem hukum Hak Kekayaan Intelektual telah ada dalam Undang-Undang Nomor 28 Tahun 2014 Tentang Hak Cipta namun belum sepenuhnya dapat diberlakukan secara optimal, karena belum adanya peraturan pelaksananya. Dalam Undang-Undang Nomor 28 Tahun 2014 Tentang Hak Cipta pengaturan tentang ekspresi budaya tradisional diatur dalam Bab V pasal 38. Kewajiban negara dalam pemeliharaan dan pengelolaan ekspresi budaya tradisional dimuat dalam Pasal 38 ayat (2) yaitu "Negara wajib menginventarisasi, menjaga dan memelihara ekspresi budaya tradisional sebagaimana dimaksud pada ayat (1)". Karena itu pemerintah baik pusat maupun daerah memegang tugas dan fungsi penting dalam perlindungan dan pemanfaatannya.

Provinsi Banten adalah salah satu provinsi di Indonesia yang paling dekat dengan Ibu Kota Negara yang memiliki keunggulan fisik geografis yang strategis. Secara administratif 4 (empat) Kabupaten yaitu, Kabupaten Pandeglang, Kabupaten Lebak, Kabupaten Serang, Kabupaten Tangerang dan 4 (empat) Kota, Kota Tangerang, Kota Cilegon, Kota Serang, Kota Tangerang Selatan ${ }^{3}$. Masing-masing daerah baik kota maupun kabupaten memiliki ekspresi budaya tradisional yang berbeda-beda. Kabupaten

\footnotetext{
${ }^{1}$ Bayangsari Wedhatami, Budi Santoso, Jurnal: Upaya Perlindungan Ekspresi Budaya Tradisional Dengan Pembentukan Peraturan Daerah, hlm. 33

2 Miranda Risang, dkk, 2014, Hukum Sumber Daya Genetic Pengetahuan Tradisional Dan Ekspresi Budaya Tradisional di Indonesia, penerbit PT Alumni, Bandung, hlm. 4

${ }^{3}$ Sulasno, Wahyuddin, Fitria Agustin, draft Jurnal PTUPT: Penerapan Kebijakan Dan Strategi Kekayaan Intelektual (KI) Serta Perlindungan Hukum Atas Produk Unggulan Daerah, Seni Dan Budaya Di Provinsi Banten
} 
Lebak dikenal sebagai daerah yang masih kental akan budaya tradisional. Terdapat banyak budaya tradisional lebak yang saat ini eksistensinya masih dilestarikan misalnya, Seba Baduy, Seren Taun, Upacara Kawal, Pokplod, Debus, Jaipongan,Toleat dan lain sebagainya.

Semua jenis ekspresi budaya tradisional tersebut sangatlah perlu memiliki perlindungan hukum dengan mengeluarkan kebijakan secara tertulis berupa peraturan perundang-undangan baik ditingkat pusat maupun daerah agar terjamin kepastian hukumnya. Salah satu isu yang pernah terjadi adalah kasus klaim pengetahuan tradisional dan ekspresi budaya tradisional yang dilakukan oleh Malaysia. Dalam sebuah iklan Discovery Channel dan Enigmatic Malaysia, ditayangkan tari Pendet, Wayang, Reog Ponorogo, yang diklaim merupakan ekspresi budaya tradisional Malaysia, padahal ketiganya merupakan ekspresi budaya tradisional Indonesia ${ }^{4}$. Agar menghindari hal tersebut pemerintah diharapkan secara aktif melakukan upaya untuk melindungi ekspresi budaya tradisional salah satunya dengan menciptakan produk hukum. Berdasarkan fenomena diatas, peneliti merumuskan masalah sebagai berikut : Bagaimana Pengembangan dan Strategi perlindungan hukum terhadap Ekspresi Budaya Tradisional di Kabupaten Lebak? Bagaimana bentuk perlindungan hukum terhadap Ekspresi Budaya Tradisional di Kabupaten Lebak?

\section{B. METODE PENELITIAN}

Metode penelitian yang digunakan dalam penelitian ini adalah dengan metode penelitian hukum normatif empiris. Metode penelitian normatif empiris merupakan penelitian melihat dari hukum yang bekerja pada segi kaidah/norma berupa peraturan perundang-undangan yang berkaitan dengan ekspresi budaya tradisional dengan tidak terlepas dari unsur sosial/empiris yakni kenyataan yang ada di masyarakat adanya pemahaman juga perlindungan yang kurang maksimal terkait ekspresi budaya tradisional. Teknik dalam pengumpulan data dengan cara studi pustaka yaitu teknik pengumpulan dan informasi dengan menelaah sumber-sumber tertulis yang relevan dan berhubungan dengan objek yang sedang diteliti sehingga mampu menjawab permasalahan yang dihadapi. Analisis data dilakukan secara kualitatif yaitu dengan menelaah seluruh data yang tersedia kemudian dilakukan reduksi data sehingga menghasilkan penafsiran data yang sesuai dengan tujuan penelitian.

\footnotetext{
${ }^{4}$ Badan Penelitian dan Pengembangan HAM Kementerian Hukum dan HAM RI, 2013, Perlindungan Kekayaan Intelektual Atas Pengetahuan Tradisional dan Ekspresi Budaya Tradisional Masyarakat Adat, penerbit P.T Alumni, Bandung, hlm.3
} 


\section{HASIL DAN PEMBAHASAN}

\section{Strategi Perlindungan Hukum Terhadap Ekspresi Budaya Tradisional di Indonesia}

Sebelum berbicara tentang konsep perlindungan hukum terhadap ekspresi budaya tradisional, lebih dulu kita harus memahami konsep perlindungan hukum secara umum yang dikemukakan oleh para ahli, yaitu Perlindungan hukum adalah memberikan pengayoman kepada hak asasi manusia yang dirugikan orang lain dan perlindungan tersebut diberikan kepada masyarakat agar mereka dapat menikmati semua hak-hak yang diberikan oleh hukum atau dengan kata lain perlindungan hukum adalah berbagai upaya hukum yang harus diberikan oleh aparat penegak hukum untuk memberikan rasa aman, baik secara pikiran maupun fisik dari gangguan dan berbagai ancaman dari pihak manapun (Rahardjo, 1993:74).

Perlindungan hukum adalah suatu perlindungan yang diberikan kepada subjek hukum dalam bentuk perangkat hukum baik yang bersifat preventif maupun bersifat represif. ${ }^{5}$ Perlindungan hukum preventif adalah upaya perlindungan hukum yang dilakukan pemerintah dengan tujuan untuk mencegah sebelum terjadinya suatu pelanggaran. Perlindungan hukum represif merupakan perlindungan akhir berupa sanksi seperti, denda, penjara, dan hukuman tambahan yang diberikan apabila sudah terjadi sengketa atau telah dilakukan pelanggaran. ${ }^{6}$ Perlindungan atas Ekspresi Budaya Tradisional diatur dalam Undang-Undang Nomor 28 Tahun 2014 Tentang Hak Cipta. Walaupun terdapat Rancangan Undang-Undang Mengenai Pengetahuan Tradisional dan Ekspresi Budaya Tradisional (RUU PTEBT) namun sampai saat ini belum diundang-undangkan.

Dalam Undang-Undang Nomor 28 Tahun 2014 Tentang Hak Cipta pasal 38 Ayat (1), (2), (3) dan (4) berbunyi sebagai berikut:

1. Hak Cipta atas Ekspresi Budaya Tradisional dipegang oleh Negara

2. Negara wajib menginventarisasi, menjaga dan memelihara Ekspresi Budaya Tradisional sebagaimana dimaksud pada Ayat (1)

3. Penggunaan Ekspresi Budaya Tradisional sebagaimana Ayat (1) harus memperhatikan nilai-nilai yang hidup dalam masyarakat pengembannya.

4. Ketentuan lebih lanjut mengenai Hak Cipta yang dipegang oleh negara atas Ekspresi Budaya Tradisional sebagaimana dimaksud pada Ayat (1) diatur dengan Peraturan Pemerintah.

\footnotetext{
${ }^{5}$ Anak Agung, Sagung Putri, jurnal: Perlindungan Hukum Ekspresi Budaya Tradisional dalam Bingkai Rezim Hak Cipta, Universitas Udayana, hlm, 10.

${ }^{6}$ Philipus M. Hadjon, 1987, Perlindungan Hukum Bagi Rakyat Indonesia, Surabaya: bina ilmu, hlm. 2
} 
Pada pasal 38 Ayat (1) Undang-Undang Nomor 28 Tahun 2014 menyebutkan Ekspresi Budaya Tradisional mencakup salah satu atau kombinasi bentuk ekspresi sebagai berikut:

1. Verbal tekstual, baik lisan maupun tulisan yang berbentuk prosa maupun puisi, dalam berbagai tema dan kandungan isi pesan, yang berbentuk karya sastra maupun narasi informatif;

2. Musik, mencakup antara lain, vokal, instrumental, atau kombinasinya;

3. Gerak, mencakup antara lain, tarian;

4. Teater, mencakup antara lain, pertunjukan wayang dan sandiwara rakyat;

5. Seni rupa, baik bentuk dua dimensi maupun tiga dimensi yang terbuat dari berbagai macam bahan seperti kulit, kayu, bambu, ,logam, batu, keramik, kertas, tekstil, dan lain-lain atau kombinasinya; dan

6. Upacara adat. Negara sebagai pemegang Hak Cipta terhadap Ekspresi Budaya Tradisional mempunyai hak eksklusif atau khusus sebagaimana dalam pengertian Hak Cipta pasal 1 angka 1 Undang-Undang Nomor 28 Tahun 2014 tentang Hak Cipta berbunyi:" Hak Cipta yaitu hak eksklusif pencipta yang timbul secara otomatis berdasarkan prinsip deklaratif setelah suatu ciptaan diwujudkan dalam bentuk nyata tanpa mengurangi pembatasan sesuai ketentuan peraturan perundang-undangan". Hak-hak eksklusif tersebut antara lain hak untuk menerbitkan, menggandakan, menerjemahkan, mengadaptasi, mentransformasi, mendistribusikan, mempertunjukkan dan mengumumkan.

Negara sebagai otoritas tertinggi, dan pemerintah daerah sebagai representasi negara dalam perlindungan dan pengaturan Ekspresi Budaya Tradisional dapat mencegah adanya monopoli atau komersialisasi serta tindakan yang merusak atau pemanfaatan oleh pihak asing tanpa seizin negara sebagai pemegang hak cipta. Dalam Pasal 60 Ayat (1) Undang-Undang Nomor 28 Tahun 2014 tentang Hak Cipta menyebutkan "Hak Cipta atas Ekspresi Budaya Tradisional yang dipegang oleh negara sebagaimana dimaksud pada Pasal 38 Ayat (1) berlaku tanpa batas waktu”. Ini jelas bertujuan untuk melindungi hak cipta atas ekspresi budaya tradisional yang dapat merugikan negara. Meskipun demikian, tujuan pada Pasal 60 Ayat (1) UndangUndang Nomor 28 Tahun 2014 tentang Hak Cipta adalah untuk melindungi karyakarya intelektual berupa seni, budaya dan adat istiadat juga nilai-nilai yang terkandung dalam masyarakat asli, namun kenyataan yang dirasakan sangatlah berbeda. Usaha negara dalam melindungi karya-karya tradisional yang dieksploitasi oleh negara lain atau pihak lain sebagai pihak asing yang tidak memiliki hak untuk mengeksploitasi dirasa kurang maksimal.

Salah satu isu yang pernah terjadi adalah kasus klaim pengetahuan tradisional dan ekspresi budaya tradisional terhadap Pendet, Wayang dan Reog Ponorogo yang 
dilakukan oleh Malaysia. Selain itu, pengetahuan pengobatan tradisional Indonesia, oleh masyarakat Jawa telah dipatenkan oleh pengusaha-pengusaha Jepang. Tercatat 39 pendaftaran paten telah diterbitkan sertifikatnya oleh Japan Patent Office (JPO). Tidak hanya itu, pematenan yang dilakukan oleh Jepang termasuk pada Ubi Cilembu yang merupakan tanaman jenis ubi yang rasanya khas dan tumbuh di daerah Jawa Barat, Indonesia. Produk olahan makanan dengan bahan dasar Ubi Cilembu ini ternyata telah dipatenkan dan merek panganan Ubi Cilembu telah didaftarkan di Jepang. Hal tersebut dapat terjadi karena dalam sisi legalitas belum tersedianya peraturan perundangundangan yang memadai dalam memberikan perlindungan hukum terhadap hak kekayaan intelektual atas ekspresi budaya tradisional.

Perlindungan ekspresi budaya tradisional melalui hukum hak cipta dipandang salah satu bentuk yang paling relevan dalam prinsip-prinsip hukum kekayaan intelektual. Namun, bukan berarti perlindungan melalui hak cipta bukan berarti tidak menemui masalah ketika persyaratan dan prinsip-prinsip perlindungan hak cipta akan diterapkan, seperti bentuk karya berwujud (fixation work), keaslian (originality), pencipta teridentifikasi (identification of author) dan jangka yang dibatasi. Dalam persyaratan bentuk karya berwujud (fixation work) dalam hukum hak cipta merupakan salah satu persyaratan yang harus dipenuhi jika suatu karya ingin mendapatkan perlindungan hukum. Persyaratan tersebut tentu menjadi hambatan apabila diterapkan pada perlindungan ekspresi budaya tradisional karena hampir sebagian besar karya budaya tradisional mempunyai karakter oral transmisi atau tidak tertulis misalnya, sebagian besar dongeng, legenda, mitos, tarian dan lagu rakyat. ${ }^{7}$ Dengan kata lain hukum hak cipta ternyata tidak sepenuhnya sesuai (compatible) dengan karakteristik perlindungan ekspresi budaya tradisional.

Perbedaan karakter antara Hak Kekayaan Intelektual pada Hak Cipta dan Ekspresi Budaya Tradisional membuat sistem hukum hak cipta tidak dapat melindungi secara utuh Ekspresi Budaya Tradisional. Walaupun sama-sama bersumber dari kreativitas intelektual manusia terdapat perbedaan mendasar antara keduanya. Perbedaan tersebut berupa perlindungan hukum hak cipta diwujudkan dalam ekspresi nyata. Selain hal itu dalam perlindungan hukum hak cipta teridentifikasi secara jelas siapa pencipta, pemegang hak cipta ataupun penemunya dan orientasi ciptaan atau temuannya lebih ke motif ekonomi. Sedangkan dalam ekspresi budaya tradisional, identifikasi pencipta asli tidak diketahui karena bersifat komunal dari masyarakat tradisional dan secara turun-menurun. Permasalahan mendasar adalah bahwa nilainilai budaya masyarakat setempat tidak mengenal kepemilikan individu terhadap suatu

\footnotetext{
${ }^{7}$ Dyah Permata Budi, 2018, Journal of Intellectual Property: Perlindungan Hukum Preventif Terhadap Ekspresi Budaya Tradisional di Daerah Istimewa Yogyakarta Berdasarkan Undang-Undang Nomor 28 Tahun 2014 Tentang Hak Cipta, Vol. 1, No. 1, hlm. 17
} 
karya dalam bidang ilmu pengetahuan, sastra dan seni. Keadaan ini tampak jelas dalam penghargaan atas kreativitas dan karya seni dalam masyarakat tradisional. ( Riswandi, 2005:204)

Ekspresi budaya tradisional merupakan milik bersama (komunal) tidak ada individu yang memiliki ekspresi budaya tradisional. Berbeda dengan Hak Cipta seperti Lagu, Merek dan Paten yang merupakan milik individual. Sehingga perlu perbedaan pengaturan komponen perlindungan yang tepat untuk diterapkan antara Hak Cipta dan ekspresi budaya tradisional. Sehingga diperlukan upaya perlindungan yang bersifat preventif juga represif. Perlindungan hukum Preventif merupakan perlindungan yang diberikan oleh pemerintah dengan tujuan untuk mencegah sebelum terjadinya suatu sengketa atau pelanggaran. Misalnya membentuk suatu peraturan perundangundangan tersendiri yang mengatur tentang ekspresi budaya tradisional dengan tujuan untuk mencegah suatu pelanggaran serta memberikan batasan-batasan dalam melakukan suatu kewajiban. Perlindungan hukum Represif yaitu perlindungan hukum akhir yang diberikan bila terjadi suatu sengketa atau pelanggaran berupa denda, penjara dan hukuman tambahan lainnya.

Kabupaten Lebak yang merupakan bagian dari Provinsi Banten mempunyai begitu banyak ekspresi budaya tradisional yang bisa dimanfaatkan pemerintah setempat untuk memajukan dan mensejahterakan masyarakatnya. Beberapa kebudayaan khas Lebak antara lain Seba Baduy, Seren Taun dan lain-lain. Salah satu perangkat hukum yang paling penting adalah basis data (data base) yang akurat tentang ekspresi budaya tradisional di Kabupaten Lebak yang nantinya akan digunakan dalam rangka melakukan klaim terhadap pihak luar yang telah melanggar hak-hak masyarakat lokal. ${ }^{8}$ Dalam hal menyajikan basis data yang akurat tidaklah mudah. Banyak yang perlu disiapkan terutama masalah anggaran yang akan dikeluarkan. Oleh karena itu perlu dipikirkan sistem basis data dan pengembangannya dengan relatif mudah dan murah. Untuk prosesnya penyajian data base bisa dilakukan dari setiap sektor baik instansi pemerintah maupun Lembaga Swadaya Masyarakat (LSM) atau warga masyarakat pada umumnya yang memiliki data atau informasi tentang ekspresi budaya tradisional di Lebak.

Untuk melindungi warisan budaya Indonesia tidak cukup dengan hanya sekedar membuat aturan hukum melainkan proses dokumentasi dan kompilasi data base budaya lokal maupun ekspresi budaya tradisional khususnya di Kabupaten Lebak merupakan hal vital untuk aspek pelestarian budaya sebagai upaya mencegah kepunahan. Apabila suatu warisan budaya tradisional pada suatu daerah punah maka hilang juga perlindungan hak kekayaan intelektual atas budaya tersebut, sebagai akibatnya budaya tersebut menjadi milik umum dan public dominan.

\footnotetext{
${ }^{8}$ Ibid, hlm, 19.
} 


\section{Perlindungan Hukum Terhadap Ekspresi Budaya Tradisional di Kabupaten Lebak}

Indonesia dikenal sebagai bangsa yang kaya baik dari sumber daya alam maupun kebudayaannya. Terdiri dari berbagai suku bangsa menjadikan Indonesia sebagai bangsa yang majemuk dan beragam, keberagaman budaya itulah yang menjadikan Indonesia memiliki begitu banyak seni dan budaya yang harus dilestarikan. ${ }^{9}$ Uniknya setiap daerah yang tersebar di Indonesia pada umumnya memiliki sistem budayanya masing-masing. Sistem budaya itu meliputi kepercayaan, sistem nilai, dan norma, ekspresi keindahan, dan cara komunikasi. Salah satu daerah tersebut adalah Kabupaten Lebak di Provinsi Banten.

Kabupaten Lebak merupakan salah satu kabupaten yang terletak di Provinsi Banten terletak antara $6^{\circ} 18^{\prime}-7^{\circ} 00^{\prime}$ Lintang Selatan dan $105^{\circ} 25^{\prime}-106^{\circ} 30^{\prime}$ Bujur Timur. Kabupaten Lebak memiliki luas wilayah $304.472 \mathrm{Ha}\left(3.044,72 \mathrm{Km}^{2}\right)$ yang terdiri atas 28 Kecamatan dengan 5 Kelurahan dan 340 Desa. Ibukota Kabupaten Lebak adalah Rangkasbitung. Kabupaten Lebak berbatasan dengan Kabupaten Serang dan Kabupaten Tangerang di utara, Kabupaten Bogor dan Kabupaten Sukabumi di timur, Samudra Hindia di selatan, serta Kabupaten Pandeglang di barat. ${ }^{10}$ Kabupaten Lebak memiliki kekhasan dalam budaya dan tradisi. Kekhasan tersebut dapat dilihat dari keragaman budaya yang berbeda dengan wilayah lain di Provinsi Banten yaitu dari dua kelompok masyarakat adat yang ada di Kabupaten Lebak. Dua kelompok masyarakat tersebut adalah Masyarakat Adat Baduy dan Masyarakat Adat Kasepuhan Banten Kidul. Kongres Kebudayaan Indonesia 2018 menyebutkan beberapa jenis Ekspresi Budaya Tradisional di Kabupaten Lebak antara lain:

1. Tradisi Lisan: Nyipohaci dan Sulanjana

2. Adat Istiadat: Munar Lembur, Ngarengkong, Ngukus di Pandaringan, Nyawang Bulan/Mapag Purnama, Nyebor, Prah Prahan, Seba Baduy, Rasul Mulud, Rasul Riwah, Sedekah Bumi, Seren Taun, dan Upacara Kawalu

3. Seni: Pokplod, Gegendeh, Beluk Saman, Koromong Baduy, Angklung Buhun, Ubrug, Dogdog Lojor, Calung Renteng, Wayang Ulin, Debus, Jaipongan, Toleat, Gondang, Cisungsang, Sintren, Karinding, Rengkong dan lain sebagainya.

4. Bahasa: Bahasa Sunda Lebak dan Bahasa Banyumasan atau Bahasa Jawa Banten

5. Olahraga Tradisional: Bebentengan, Egrang/Jajangkungan, Galah Asin, OrayOrayan, Dagongan, Lari Balok, Patok Lele, dan Sumpitan.

\footnotetext{
${ }^{9}$ Yollanda Oktavitri, Jurnal: Resepsi Masyarakat Kabupaten Lebak Provinsi Banten Terhadap Upacara Seba Suku Baduy, hlm. 2

${ }^{10}$ Sulasno, Wahyuddin, Fitria Agustin, Op.Cit, hlm. 5.
} 
Keanekaragaman budaya tersebut tentunya menjadi kebanggaan masyarakat dan merupakan aset yang tidak ternilai bagi pemerintah daerah, karena menjadi nilai jual bagi wisatawan yang berkunjung ke Kabupaten Lebak. Salah satu lembaga yang berperan dalam rangka pelestarian dan pengembangan kebudayaan Indonesia adalah Kementerian Pendidikan dan Kebudayaan Republik Indonesia. Dalam Peraturan Menteri Pendidikan dan Kebudayaan Republik Indonesia Nomor 11 Tahun 2015 Tentang Organisasi dan Tata Kerja Kementerian Pendidikan dan Kebudayaan Pasal 2 menyebutkan tugas dari Kementerian Pendidikan dan Kebudayaan adalah menyelenggarakan urusan pemerintahan di bidang anak usia dini, pendidikan dasar, pendidikan menengah, dan pendidikan masyarakat serta pengelolaan kebudayaan untuk membantu presiden dalam menyelenggarakan pemerintahan negara. Pasal 561 Ayat (2) Peraturan Menteri Pendidikan dan Kebudayaan Republik Indonesia Nomor 11 Tahun 2015 Tentang Organisasi dan Tata Kerja Kementerian Pendidikan dan Kebudayaan menyebutkan, mengenai pengelolaan dalam rangka perlindungan terhadap Ekspresi Budaya Tradisional yang menjadi tugas dari Subdit Pengetahuan dan Ekspresi Budaya Tradisional dalam hal ini seksi Ekspresi Budaya Tradisional mempunyai tugas melakukan penyusunan bahan perumusan, koordinasi, dan pelaksanaan kebijakan, norma, standar, prosedur, kriteria, bimbingan teknis dan supervisi, pembinaan dan pelestarian, evaluasi dan laporan di bidang Ekspresi Budaya Tradisional.

Salah satu cara perlindungan ekspresi budaya tradisional juga dapat dilakukan melalui arsip dan dokumentasi nasional di tiap-tiap negara sehingga setiap orang dapat menemukan ekspresi budaya tradisional yang terdapat di negara masing-masing (Rafian dan Sabrina, 2014: 504). Pencatatan warisan budaya juga dianggap karena beberapa elemen warisan budaya tak benda mulai terancam punah. Guna menghindari hal tersebut pemerintah mulai tanggap dan menetapkan perlindungan warisan tak benda melalui Peraturan Presiden Nomor 78 Tahun 2007 Tentang Pengesahan Convention for The Safeguarding of The Intangible Cultural Heritage yaitu konvensi untuk perlindungan warisan budaya tak benda.

Hukum dalam kehidupan bermasyarakat bertujuan untuk menjaga dan melindungi kepentingan-kepentingan masyarakat dari hal-hal yang bertentangan sehingga menghindari segala bentuk sengketa di dalamnya. Seperti yang kita tahu bahwa Indonesia adalah negara hukum yang berarti segala bentuk aktivitas di negara Indonesia harus ada pengaturan hukumnya. Ketentuan hukum dan segala peraturan yang dibuat oleh masyarakat merupakan kesepakatan bersama untuk mengatur hubungan perilaku diantara anggota masyarakat-masyarakat dan antara perseorangan dengan pemerintah yang dianggap mewakili kepentingan masyarakat. 
Dalam UUD 1945 memberikan perlindungan hukum bagi setiap warga negara Indonesia tanpa terkecuali, untuk itu setiap produk atau kebijakan yang dikeluarkan baik dari lembaga legislatif atau pemerintah daerah harus senantiasa memberikan jaminan perlindungan hukum bagi setiap warganya. Bahkan harus mampu menangkap aspirasi-aspirasi hukum dan keadilan yang berkembang di masyarakat. Berdasarkan hasil penelitian perlindungan ekspresi budaya tradisional di Kabupaten Lebak belum maksimal karena belum adanya aturan dan kebijakan yang bersifat teknis tentang perlindungan hukum atas ekspresi budaya tradisional di Kabupaten Lebak. Hal tersebut sangat mungkin terjadi karena dalam lingkup pemerintah pusat pula belum terbentuk peraturan perundang-undangan khusus tentang ekspresi budaya tradisional. Padahal kebijakan berupa produk hukum seperti Undang-Undang dirasa sangat perlu dibentuk sebagai jaminan adanya kepastian hukum.

\section{KESIMPULAN}

Perlindungan hukum ekspresi budaya tradisional melalui hukum hak cipta saat ini dianggap salah satu bentuk yang paling relevan dalam prinsip-prinsip hukum kekayaan intelektual. Namun bukan berarti hal tersebut tidak mengalami permasalahan, ketika adanya perbedaan karakteristik antara Ekspresi Budaya Tradisional seperti pada karya berwujud, keaslian, pencipta teridentifikasi dan jangka waktu yang dibatasi menjadi hal yang mendasar untuk dibentuk peraturan perundang-undangan tersendiri tentang Ekspresi Budaya Tradisional. Karena dari perbedaan karakteristik tersebut hukum hak cipta tidak cukup mampu melindungi ekspresi budaya tradisional.

Belum adanya belum adanya aturan dan kebijakan yang bersifat teknis tentang perlindungan hukum atas ekspresi budaya tradisional di Kabupaten Lebak, hal ini mungkin terjadi karena pada lingkup pemerintah pusat pula belum terbentuk peraturan perundang-undangan yang secara khusus mengatur Ekspresi Budaya Tradisional.

Penulis mengharapkan peran pemerintah pusat dan pemerintah daerah dalam penjaminan hukum terhadap ekspresi budaya tradisional dengan membuat peraturan perundang-undangan yang khusus untuk ekspresi budaya tradisional agar mendapatkan perlindungan hukum secara pasti dan terhindar dari sengketa seperti klaim-klaim negara lain. 


\section{DAFTAR PUSTAKA}

\section{Buku :}

Badan Penelitian dan Pengembangan HAM Kementrian Hukum dan HAM RI, 2013, Perlindungan Kekayaan Intelektual Atas Pengetahuan Tradisional dan Ekspresi Budaya Tradisional Masyarakat Adat, penerbit P.T Alumni, Bandung

Hadjon, M. Philipus, 1987, Perlindungan Hukum Bagi Rakyat Indonesia, Surabaya: Bina Ilmu

Imaniyati, Neni Sri dan Putra ,Panji Adam Agus, 2017, Hukum Bisnis, Penerbit, Refika Aditama, Cetakan Kesatu

Risang, Miranda, dkk, 2014,Hukum Sumber Daya Genetic Pengetahuan Tradisional Dan Ekspresi Budaya Tradisional di Indonesia, penerbit PT Alumni, Bandung

Roisah Kholis, 2015, Konsep Hukum Hak Kekayaan Intelektual 9Sejarah, Pengertian dan Filosofi Pengakuan HKI dari masa ke masa, Setara Press Malang

Sardjono, Agus, 2010, Hak Kekayaan Intelektual dan Pengetahuan Tradisional, Bandung : PT. Alumni

\section{Jurnal :}

Anak Agung, Sagung Putri, jurnal: Perlindungan Hukum Ekspresi Budaya Tradisional dalam Bingkai Rezim Hak Cipta, Universitas Udayana

Bayangsari Wedhatami, Budi Santoso, Jurnal: Upaya Perlindungan Ekspresi Budaya Tradisional Dengan Pembentukan Peraturan Daerah

Dyah Permata Budi, 2018, Journal of Intellectual Property: Perlindungan Hukum Preventif Terhadap Ekspresi Budaya Tradisional di Daerah Istimewa Yogyakarta Berdasarkan Undang-Undang Nomor 28 Tahun 2014 Tentang Hak Cipta, Vol. 1, No. 1

Sulasno, Wahyuddin, Fitria Agustin, draft Jurnal PTUPT:Penerapan Kebijakan Dan Strategi Kekayaan Intelektual (KI) Serta Perlindungan Hukum Atas Produk Unggulan Daerah, Seni Dan Budaya Diprovinsi Banten

Yolanda Oktavitri, Jurnal: Persepsi Masyarakat Kabupaten Lebak Provinsi Banten Terhadap Upacara Seba Suku Baduy.

\section{Peraturan Perundang-Undangan :}

Undang-Undang Nomor 28 Tahun 2014 tentang Hak Cipta. (TLN) 5599

Peraturan Menteri Pendidikan dan Kebudayaan Republic Indonesia Nomor 11 Tahun 2015 Tentang Organisasi dan Tata Kerja Kementrian Pendidikan 
AJUDIKASI : Jurnal Ilmu Hukum, Volume 5 Nomor 1, Juni 2021. Hlm 71-82

P-ISSN 2613-9995 \& E-ISSN 2614-0179 